DOI: http://dx.doi.org/10.18203/2320-1770.ijrcog20171938

\title{
Antenatal thyroid screening and its clinical correlation
}

\author{
Juhi Sisodia*, Meena Samant
}

Department of Obstetrics and Gynecology, Kurji Holy Family Hospital, Patna, Bihar, India

Received: 04 February 2017

Revised: 04 February 2017

Accepted: 23 March 2017

\author{
*Correspondence: \\ Dr. Juhi Sisodia, \\ E-mail: sisodiajuhi@yahoo.co.in
}

Copyright: () the author(s), publisher and licensee Medip Academy. This is an open-access article distributed under the terms of the Creative Commons Attribution Non-Commercial License, which permits unrestricted non-commercial use, distribution, and reproduction in any medium, provided the original work is properly cited.

\begin{abstract}
Background: The study of hypothyroidism in pregnancy was done with the aim of determining the effect of hypothyroidism on maternal and perinatal outcome. This study also aimed to decide whether universal screening of pregnant women for hypothyroidism is justified.

Methods: A prospective observational study was done over a period of 1 year from October 2011 to September 2012, on pregnant women attending the OPD of Obs and Gynae department. Serum TSH is the most convenient and best test to diagnose hypothyroidism in pregnancy in first trimester. Ideal serum TSH level during pregnancy is 0.5 $2.5 \mu \mathrm{IU} / \mathrm{ml}$ in first trimester and $0.5-3 \mu \mathrm{IU} / \mathrm{ml}$ in second and third trimester. First trimester booking visit is the ideal time for initial evaluation. Thereafter serum TSH should be measured at 6 weeks interval for necessary dose adjustments. Levothyroxine is the drug of choice. It should be started at $1.6-2 \mu \mathrm{g} / \mathrm{kg} / \mathrm{day}$. If serum TSH is raised but fT4 is normal, treatment can be started with $25-75 \mu \mathrm{g} / \mathrm{day}$.

Results: Inadequately treated hypothyroid pregnant women had higher incidence of maternal complications in comparison to adequately treated hypothyroid patients, like threatened abortion (11.1\% vs $1.5 \%)$, antepartum hemorrhage (7.4\% vs $1.5 \%)$, premature rupture of membrane (14.8\% vs $3.0 \%)$, preterm labour $(18.5 \%$ vs $1.5 \%)$, postpartum hemorrhage $(9.3 \%$ vs $4.5 \%)$, anemia $(16.7 \%$ vs $9.1 \%)$ and intrauterine death $(9.3 \%$ vs $0 \%)$. Perinatal complications were also higher like fetal distress (33.3\% vs 13.6\%) and low birth weight (16.7\% vs $4.5 \%)$.

Incidence of caesarean section was higher in hypothyroid women in comparison to control group (29.2\% vs $19.2 \%)$.

Conclusions: This study shows that there is an association between inadequately treated hypothyroidism and adverse maternal and perinatal outcome. Those who were detected early and adequately treated had outcome similar to control group.
\end{abstract}

Keywords: Euthyroid, Hypothyroidism, Levothyroxine, TSH

\section{INTRODUCTION}

Thyroid disorders are one of the commonest endocrine disorders in pregnancy. Hypothyroidism is often overlooked in pregnancy because of nonspecific symptoms which may be masked by obstetric symptoms like increase in weight and altered appetite. But a clinician must consider thyroid dysfunction as a possibility in pregnant women and differentiate normal physiological changes from thyroid disease.
Overt hypothyroidism is defined as increase in serum TSH associated with decrease in concentration of thyroxine. Subclinical hypothyroidism is an increase in serum TSH associated with normal concentration of thyroxine

The adverse maternal outcomes include miscarriage, PIH, pre-eclampsia, placental abruption, anaemia, $\mathrm{PPH}$ and pre-term labour. ${ }^{1-3}$ The adverse perinatal outcomes include low birth weight, fetal distress, increase in 
admission to neonatal ICU, neonatal hypothyroidism, IUGR and IUD. ${ }^{1-3}$

Thyroid disorders satisfy most of the criteria for a disease to warrant population screening. ${ }^{4}$ They are common and treatable.

The objectives of this study were:

- To study the relationship between maternal hypothyroidism and obstetrical complications.

- To study the effect of maternal hypothyroidism on perinatal outcome.

- To compare pregnancy outcome in adequately treated and inadequately treated (those detected after first trimester or non-compliant) women with hypothyroidism

\section{METHODS}

This is an observational prospective cohort study.

The cases of this study were recruited from the OutPatient Department of Obstetrics and Gynaecology over a period of one year from October 2011 to September 2012.

\section{Inclusion criteria}

Control group: 120 pregnant women with normal thyroid hormone levels were selected in this group.

Study group: 120 pregnant women with raised serum TSH level were selected in this group (hypothyroid).

\section{Exclusion criteria}

Pregnant women with pre-existing medical disorders like diabetes, heart disease, collagen disease etc. Women taking drugs known to alter thyroid level (e.g. amphetamines, dopamine agonist, amiodarone, steroids)

Detailed history was taken. General physical examination and obstetric examination was done. Routine antenatal investigations were done.

When TSH was elevated, fT3 and fT4 were done to confirm diagnosis.

Trimester specific TSH ranges were used $0.1 \mu \mathrm{IU} / \mathrm{ml}$ $2.5 \mu \mathrm{IU} / \mathrm{ml}$ in first trimester, $0.2 \mu \mathrm{IU} / \mathrm{ml}-3 \mu \mathrm{IU} / \mathrm{ml}$ in second trimester and $0.3 \mu \mathrm{IU} / \mathrm{ml}-3 \mu \mathrm{IU} / \mathrm{ml}$ third trimester. All women with TSH value above these received levothyroxine tablets empty stomach.

Out of total 120 hypothyroid pregnant women, 83 were diagnosed hypothyroid since first trimester. 16 were known cases of hypothyroidism, who conceived while on thyroxine replacement dose. 67 were diagnosed for the first time during pregnancy in the first trimester. Levothyroxine was started from the first trimester.

66 out of 83 patients took adequate replacement dosage of thyroxine. They were selected as study group A women.

17 out of 83 women lost follow up or had irregular ANC visits due to which adequate control could not be maintained and 37 patients were diagnosed as hypothyroid during second / third trimester. All these 54 women were selected as study group B women.

Levothyroxine is the treatment of choice. Thyroxine treatment was titrated according to body weight. In overt hypothyroidism, treatment was started with $1.6-2.0 \mu \mathrm{g} / \mathrm{kg}$ body weight/day. In subclinical hypothyroidism, treatment was started with $25-75 \mu \mathrm{g} /$ day. Once treatment was initiated TSH was repeated at 6 weeks. Necessary adjustments were made in dose. All pregnant women were followed throughout pregnancy and delivery.

Quantitative and qualitative variables were compared with Fischer's t-test. Other data calculated were mean and standard deviation.

\section{RESULTS}

A total of 200 hypothyroid pregnant women attended the OPD of Obstetrics and Gynecology, from October 2011 to September 2012. Total number of pregnant women (new cases) attending the OPD was 5386. This gives the prevalence of hypothyroidism in pregnancy $-3.7 \%$.

Table 1: Age group.

\begin{tabular}{|lllll|}
\hline $\begin{array}{l}\text { Age } \\
\text { group } \\
\text { (yrs) }\end{array}$ & \multicolumn{2}{l}{$\begin{array}{l}\text { Hypothyroid } \\
\text { pregnant women } \\
\text { (study group) }\end{array}$} & \multicolumn{2}{l|}{$\begin{array}{l}\text { Euthyroid } \\
\text { pregnant } \\
\text { (contromen group) }\end{array}$} \\
\hline & Number & $\%$ & Number & \% \\
\hline $15-19$ & 0 & 0.0 & 4 & 3.3 \\
\hline $20-24$ & 57 & 47.5 & 44 & 36.7 \\
\hline $25-29$ & 47 & 39.2 & 49 & 40.9 \\
\hline $30-34$ & 14 & 11.7 & 19 & 15.8 \\
\hline $35-40$ & 2 & 1.7 & 4 & 3.3 \\
\hline Total & 120 & 100 & 120 & 100 \\
\hline
\end{tabular}

The age of hypothyroid pregnant women varied from 2035 years, with median age of 25 years. In control group the age group varied from 19-38 years, with median age of 25 years. There was no significant difference observed regarding age in cases and control group $(\mathrm{p}>0.05)$.

Table 2: Clinical groups.

\begin{tabular}{|lll|}
\hline Clinical group & Number & $\%$ \\
\hline Study group A & 66 & 55.0 \\
\hline Study group B & 54 & 45.0 \\
\hline Total & 120 & 100 \\
\hline
\end{tabular}


Study group A

Out of total 120 hypothyroid pregnant women, 66 (55\%) patients took adequate replacement dosage of thyroxine. They maintained euthyroid status. They were selected as study group A.
Study group B

Out of total 120 hypothyroid pregnant women, 54 (45\%) patients could not maintain euthyroid status during pregnancy because they were detected during second / third trimester or they were non-compliant with therapy. They were selected as study group B.

Table 3: Maternal complications.

\begin{tabular}{|lllllllll|}
\hline Complications & $\begin{array}{l}\text { Hypothyroid pregnant } \\
\text { women (studly group) }\end{array}$ & \multicolumn{2}{l}{$\begin{array}{l}\text { Euthyroid pregnant } \\
\text { women (control group) }\end{array}$} & Relative risk & p value & t value \\
\hline Sumber & $\mathbf{\%}$ & Number & \% & & & \\
\hline Spontaneous abortion & 6 & 5.0 & 0 & 0.0 & - & $<0.05$ & 2.51 \\
\hline Threatened abortion & 7 & 5.8 & 1 & 0.8 & 7 & $<0.05$ & 2.19 \\
\hline APH & 5 & 4.2 & 1 & 0.8 & 5 & $<0.05$ & 1.70 \\
\hline PROM & 10 & 8.3 & 1 & 0.8 & 10 & $<0.01$ & 2.83 \\
\hline Preterm labour & 11 & 9.2 & 1 & 0.8 & 11 & $<0.01$ & 2.19 \\
\hline PPH & 8 & 6.7 & 5 & 4.2 & 1.6 & $>0.05$ & 0.85 \\
\hline anemia & 15 & 12.5 & 13 & 10.8 & 1.2 & $>0.05$ & 0.41 \\
\hline IUD & 5 & 4.2 & 1 & 0.8 & 5 & $<0.05$ & 1.70 \\
\hline
\end{tabular}

Table 4: Comparison of maternal complications of study group a with study group B.

\begin{tabular}{|llllllll|}
\hline Complications & \multicolumn{2}{l}{$\begin{array}{l}\text { Study group A } \\
\text { (total 66 patients) }\end{array}$} & \multicolumn{2}{l}{$\begin{array}{l}\text { Study group B } \\
\text { (total 54 patients) }\end{array}$} & Relative risk & p value & t value \\
\hline Spontaneous abortion & Number & $\mathbf{\%}$ & Number & \% & & & \\
\hline Threatened abortion & 1 & 9.1 & 0 & 0.0 & - & $<0.05$ & 2.57 \\
\hline APH & 1 & 1.5 & 6 & 11.1 & 0.2 & $<0.05$ & 2.12 \\
\hline PROM & 1.5 & 4 & 7.4 & 0.2 & $>0.05$ & 1.53 \\
\hline Preterm labour & 2 & 3.0 & 8 & 14.8 & 0.2 & $<0.05$ & 2.24 \\
\hline PPH & 1 & 1.5 & 10 & 18.5 & 0.1 & $<0.01$ & 3.09 \\
\hline Anaemia & 3 & 4.5 & 5 & 9.2 & 0.6 & $>0.05$ & 1.02 \\
\hline IUD & 6 & 9.1 & 9 & 16.7 & 0.7 & $>0.05$ & 1.23 \\
\hline
\end{tabular}

Table 5: Perinatal complications.

\begin{tabular}{|lllllll|l|}
\hline Complications & $\begin{array}{l}\text { Hypothyroid pregnant } \\
\text { women (study groujp) }\end{array}$ & \multicolumn{2}{l}{$\begin{array}{l}\text { Euthyroid pregnant } \\
\text { women (control group) }\end{array}$} & $\begin{array}{l}\text { Relative } \\
\text { risk }\end{array}$ & p value \\
& Number & \% & Number & \% & & \\
\hline Fetal distress & 27 & 22.5 & 10 & 8.3 & 2.7 & $<0.01$ & 3.11 \\
\hline LBW & 12 & 10.0 & 3 & 2.5 & 4 & $<0.05$ & 2.43 \\
\hline Neonatal hypothyroidism & 7 & 5.8 & 0 & 0.0 & - & $<0.05$ & 2.72 \\
\hline
\end{tabular}

Table 6: Comparison of perinatal complications of study group a with study group B.

\begin{tabular}{|c|c|c|c|c|c|c|c|}
\hline \multirow[t]{2}{*}{ Complications } & \multicolumn{2}{|c|}{$\begin{array}{l}\text { Study group A } \\
\text { (total } 66 \text { patients) }\end{array}$} & \multicolumn{2}{|c|}{$\begin{array}{l}\text { Study group B } \\
\text { (total } 54 \text { patients) }\end{array}$} & \multirow[t]{2}{*}{ Relative risk } & \multirow[t]{2}{*}{ p value } & \multirow[t]{2}{*}{ t value } \\
\hline & Number & $\%$ & Number & $\%$ & & & \\
\hline Fetal distress & 9 & 13.6 & 18 & 33.3 & 0.5 & $<0.05$ & 2.57 \\
\hline LBW & 3 & 4.5 & 9 & 16.7 & 0.3 & $<0.05$ & 2.15 \\
\hline Neonatal hypothyroidism & 5 & 7.6 & 2 & 3.7 & 2.5 & $>0.05$ & 0.94 \\
\hline
\end{tabular}

In hypothyroid women group, the rate of maternal complications spontaneous abortion, threatened abortion, antepartum hemorrhage, premature rupture of membrane, pre-term labour and intrauterine death was found to be higher than euthyroid women group and the difference 
between the two is statistically significant as shown by $\mathrm{p}$ value.

In women with adequately controlled thyroid levels (study group A), the rate of maternal complications threatened abortion, premature rupture of membranes, preterm labour and intrauterine death was lower than in women with inadequately controlled thyroid levels (study group B) and the difference is statistically significant as shown by p-value.

In the hypothyroid women group, rate of perinatal complications - fetal distress, low birth weight and neonatal hypothyroidism was found to be higher than euthyroid women group and the difference is statistically significant as shown by p-value.
In women with adequately controlled thyroid levels (study group A), the rate of perinatal complications -fetal distress and low birth weight was lower than in women with inadequately controlled thyroid levels (study group B) and the difference is statistically significant as shown by p-value.

In the hypothyroid group, LSCS was done in 35 (29.2\%) women and vaginal delivery in $79(65.8 \%)$.

In the control group, LSCS was done in 23 (19.2\%) women and vaginal delivery in $97(80.8 \%)$ women.

In the hypothyroid group, 3 (2.5\%) women needed LSCS for breech presentation. While in control group, 5 (4.2\%) women needed LSCS for breech presentation. $\mathrm{p}$ value $>0.05$. The difference is not statistically significant.

Table 7: Mode of delivery.

\begin{tabular}{|llllll|}
\hline & $\begin{array}{l}\text { Hypothyroid pregnant women } \\
\text { (study group) }\end{array}$ & \multicolumn{2}{l}{$\begin{array}{l}\text { Euthyroid pregnant women } \\
\text { (control group) }\end{array}$} & Relative risk \\
\hline Number & \% & Number & \% & \\
\hline LSCS & 35 & 29.2 & 23 & 19.2 & 1.5 \\
\hline Vaginal delivery & 79 & 65.8 & 97 & 80.8 & 0.8 \\
\hline
\end{tabular}

Table 8: Indication for LSCS.

\begin{tabular}{|llllllll|} 
& \multicolumn{2}{l}{$\begin{array}{l}\text { Hypothyroid pregnant } \\
\text { women (study group) }\end{array}$} & \multicolumn{2}{l}{$\begin{array}{l}\text { Euthyroid pregnant } \\
\text { women (control group) }\end{array}$} & Relative risk & p value & t value \\
& Number & \% & Number & \% & & & \\
\hline Breech & 3 & 2.5 & 5 & 4.2 & 0.6 & $>0.05$ & 0.73 \\
\hline Fetal distress & 23 & 19.2 & 10 & 8.3 & 2.3 & $<0.05$ & 2.48 \\
\hline NPOL & 1 & 0.8 & 3 & 2.5 & 0.3 & $<0.01$ & 3.39 \\
\hline Previous CS & 8 & 6.7 & 5 & 4.2 & 1.6 & $>0.05$ & 0.85 \\
\hline
\end{tabular}

In the hypothyroid group, LSCS was done in 23 (19.2\%) women for fetal distress, while in control group, in 10 $(8.3 \%)$ women for fetal distress. $p$ value $<0.05$, which is statistically significant.

In the hypothyroid group, $1(0.8 \%)$ woman had nonprogress of labour and LSCS was done. In control group, $3(2.5 \%)$ women had non-progress of labour and LSCS was done. $\mathrm{p}$ value $<0.01$, which is significant.

In hypothyroid group, in $8(6.7 \%)$ women LSCS was done for previous LSCS. In control group, in 5 (4.2\%) women LSCS was done for previous LSCS. p value $>0.05$. The difference is not statistically significant.

\section{DISCUSSION}

\section{Prevalence}

Total number of pregnant women attending the OPD from October 2011 to September 2012 was 5386. 200 of them were hypothyroid. Thus, the prevalence of hypothyroidism in pregnancy is $3.7 \%$.

Western literature reports incidence of hypothyroidism in pregnancy to be around $2.5 \%$. Studies from North India show a high prevalence of hypothyroidism in pregnancy. A study from Maulana Azad Medical College, New Delhi, 2011 concluded that subclinical hypothyroidism is common in North India. ${ }^{5}$ A study done at Government Medical College and Hospital, Chandigarh, 2012 showed prevalence of hypothyroidism was $6.3 \% .^{3}$

\section{Age}

In our study, the age of hypothyroid pregnant women ranged from $20-35$ years (mean \pm std $25.64 \pm 3.48$ ). The age in control group ranged from 19-38 years ( $\mathrm{m} \pm$ std$25.97 \pm 4.10)$. Western literature shows $63 \%$ patients in age group 30-35 years. Recent study done in Mumbai, India in 2007 reported mean age of presentation to be $25.19 \pm 4.17$ which is comparable to our result. ${ }^{6}$ The mean age at presentation in our study is lower compared to 
western countries because of early marriage and conception in India.

\section{TSH level reference range and thyroxine dose}

There has been a great deal of controversy and confusion regarding the level of serum TSH during pregnancy. An International Task Force was created under auspices of The Endocrine Society. ${ }^{7}$ Present study is based on their recommendations. Some of their recommendations are:

- In patients diagnosed with overt hypothyroidism during pregnancy, start therapy with full replacement dose of levothyroxine. $1.6-2.0 \mu \mathrm{g} / \mathrm{kg} / \mathrm{day}$ to normalize thyroid function tests as rapidly as possible.

- Subclinical hypothyroidism has been shown to be associated with an adverse outcome for both mother and offspring and hence should be treated with levothyroxine. fT4 and TSH should be tested every 6 weeks and appropriate dose adjustments should be done to maintain the target TSH levels $\leq 2.5 \mu \mathrm{IU} / \mathrm{ml}$ in first trimester and $3 \mu \mathrm{IU} / \mathrm{ml}$ in second and third trimester.

- Patients with pre-existing hypothyroidism should have their levothyroxine dose increased as soon as pregnancy is diagnosed to maintain euthyroid status. Patients should have their TSH levels assessed as soon as possible after conception and at 6 weeks interval thereafter till delivery.

- Post-delivery the patient should be reverted back to the pre-pregnant dosage and TSH should be rechecked after 6 weeks.

\section{Maternal and perinatal complications}

Among the hypothyroid pregnant women, Study Group A patients who maintained euthyroid status by adequate replacement dosage had low incidence of adverse outcome. Study Group B patients who were detected after first trimester (requirement is maximum in first trimester) or who were non-compliant with treatment had high incidence of adverse outcome.

Spontaneous abortion occurred in $6(5 \%)$ hypothyroid pregnant women. No women in control cohort had spontaneous abortion. Present study is consistent with various studies showing hypothyroidism as a cause of abortion. Various other studies of Negro et al, Namibiar et al and Pradhan et al showing such results. ${ }^{1,2,6}$

Threatened abortion was found in $7(5.8 \%)$ hypothyroid women. In control cohort, $1(0.8 \%)$ had threatened abortion. Thyroid hormone is important in maintaining early pregnancy and hypothyroid women are at risk of threatened abortion. Thyroid hormone is important in maintaining early pregnancy and thyroid receptors have been found in placental tissue. T3, in physiologic concentrations, down regulates the apoptosis of early placental extravillous tissue through the inhibition of Fas and Fas ligand. Our result is consistent with the study result of Pradhan et al in 2012. ${ }^{2}$

5 (4.2\%) hypothyroid pregnant and $1(0.8 \%)$ women from control cohort had placental abruption. $\mathrm{p}$ value $<0.05$ shows a significant association.

Premature rupture of membrane occurred in $10(8.3 \%)$ hypothyroid pregnant women and in $1(0.8 \%)$ euthyroid pregnant women. $\mathrm{p}$ value being $<0.01$, the result is significant. Similar results were reported by Goel et al. ${ }^{3}$

In present study, $11(9.2 \%)$ hypothyroid women had preterm labour and $1(0.8 \%)$ of control cohort had preterm labour. $\mathrm{p}$ value $<0.01$. Autoimmunity has been considered as basis of it. Out of 11, 4 had premature rupture of membrane, so infection and other associated etiology cannot be ruled out. Pradhan et al 2012 reported in their study, preterm delivery as a complication of hypothyroidism. $^{2}$

Postpartum haemorrhage was seen in $8(6.7 \%)$ women in hypothyroid cohort while in $5(4.2 \%)$ women in control cohort. $\mathrm{p}$ value $>0.05$ shows no significant association. Thyroxine deficiency has been linked to arterial stiffness and studies have been done to identify effects such as reduced uterine contractility. More work is needed and our study did not show any association with PPH.

In present study 15 (12.5\%) hypothyroid pregnant women had anemia whereas in control group $13(10.8 \%)$. Such high incidence in both groups can be linked to poor dietary habits in local population. Hypothyroidism has been found to be cause of macrocytic anemia which is unresponsive to Vit B12 and folate.

Raised maternal serum TSH is associated with increased risk of fetal death. In present study, there were 5 (4.2\%) intrauterine deaths. 4 were diagnosed late in pregnancy. In control group $1(0.8 \%)$ had intrauterine death. $\mathrm{p}$ value $<0.05$ shows significant association. Frequency of intrauterine death is more in the hypothyroid women who are not on thyroxine replacement therapy. This can be explained by the fact that, inadequate thyroid hormone levels early in gestation may produce irreversible changes in the fetoplacental and fetal vascular beds that would impair subsequent circulatory responses to the stress of labour. This would lead to fetal distress followed by intrauterine death.

In present study, low birth weight was seen in $12(10 \%)$ hypothyroid women and in $3(2.5 \%)$ euthyroid women. All low birth weight babies were not small for gestational age. Similar incidence was reported by Pradhan et al in their study. ${ }^{2}$ Significant association can be explained by chronic utero-placental insufficiency causing growth retardation. 


\section{Effect of treatment during pregnancy}

In present study, the incidence of complications in hypothyroid pregnant women was high in comparison to euthyroid pregnant women as shown by various studies. In our study $43.3 \%$ hypothyroid women had some sort of adverse maternal outcome versus $18.3 \%$ for euthyroid women. The incidence of perinatal complications was $34.2 \%$ and $10.8 \%$ in hypothyroid and euthyroid pregnant women, respectively.

Among the hypothyroid pregnant women, Study Group A women who were on treatment since pre-conceptional period or who were diagnosed and put on treatment since first trimester had low incidence of maternal and perinatal complications. Maternal complications were seen in $19.7 \%$ and perinatal complications in $24.2 \%$ women. Study group B who were diagnosed after first trimester or who were non-compliant with medication had high incidence of maternal and perinatal complications. Maternal complications in $72.2 \%$ and perinatal complications in $46.3 \%$ women. Treatment with levothyroxine reduced the rate of complications.

The rate of complications in treated hypothyroidism is similar to euthyroid women in present study. Hence, our study strongly suggests early screening and treatment. Thung et al and Horacek et al strongly advocate screening of hypothyroidism in pregnancy. ${ }^{4,8}$

\section{Mode of delivery}

In present study, caesarean section was needed in 35 $(29.2 \%)$ hypothyroid women and in 23 (19.2\%) women of control cohort. Most common indication of caesarean section in hypothyroid cohort was fetal distress. This is in congruence with the study of Matalon et al. ${ }^{9}$ They reported higher incidence of caesarean deliveries in hypothyroid patients $(20.1 \%$ vs $11.5 \%$, p <0.001). Sharma et al reported that caesarean section was needed in 24 out of $41(61.4 \%)$ hypothyroid women. Most common indication being fetal distress $(28.2 \%) .{ }^{10}$ Idris et al reported caesarean section rate of $28.75 \%$ in hypothyroid women. ${ }^{11}$

\section{CONCLUSION}

The study of hypothyroidism in pregnancy was done with the aim of determining effect of hypothyroidism on maternal and perinatal outcome. This study also aimed to decide whether universal screening of pregnant women for hypothyroidism is justified.

Serum TSH is the most convenient and best test to diagnose hypothyroidism in pregnancy in first trimester. First trimester booking visit is the ideal time for initial evaluation. Thereafter serum TSH should be measured at 6 weeks interval for necessary dose adjustments. Levothyroxine is the drug of choice.
Inadequately treated hypothyroid pregnant women had higher incidence of maternal complications and perinatal complications in comparison to adequately treated hypothyroid patients. Those who were detected early and adequately treated had outcome similar to control group.

Prevalence of hypothyroidism is high in reproductive age group. Inadequately treated hypothyroidism adversely affects pregnancy. Hence, universal screening of hypothyroidism should be done at first trimester booking and levothyroxine replacement dose should be started in patients to improve maternal and perinatal outcome.

\section{Funding: No funding sources Conflict of interest: None declared Ethical approval: Not required}

\section{REFERENCES}

1. Negro R, Schwartz A, Gisnondi R, Tinelli A, Mangieri T, Stagnaro-Green A. Universal screening versus case finding for detection and treatment of thyroid hormone dysfunction during pregnancy. J Clin Endocrinol Metab. 2010;95:1699-707.

2. Pradhan M, Anand B, Singh N, Mehrotra M. Thyroid peroxidase antibody in hypothyroidism: Its effect on pregnancy. J Matern Fetal Neonatal Med. 2013;26(6):581-3.

3. Goel P, Kaur J, Saha PK, Tandon R, Devi L. Prevalence, associated risk factors and effects of hypothyroidism in pregnancy: A study from North India. Gynecol Obstet Invest. 2012;74(2):89-94.

4. Thung SF, Funai EF, Grobman WA. The cost effectiveness of universal screening in pregnancy for subclinical hypothyroidism. Am J Obstet Gynecol. 2009;200(3):267.

5. Dhanwal DK, Prasad S, Agarwal AK, Dixit V, Banerjee AK. High prevalence of subclinical hypothyroidism during first trimester of pregnancy in North India. Indian J Endocr Metab. 2013;17:281-4.

6. Nambiar V, Jagtap VS, Sarathi V, Lila AR, Kamalanathan S, Bandgar TR, Menon PS, Shah NS. Prevalence and impact of thyroid disorders on maternal outcome in Asian-Indian pregnant women. J Thyroid Res. 2011;2011:429097.

7. Stricker R, Enhenard M, Eberhert R, Chevailler MC, Perez V, Quinn FA et al. Evaluation of maternal thyroid function in pregnancy: importance of using gestational age specific reference range. Eur $\mathbf{J}$ Endocrinol. 2007;157:509-14.

8. Horacek J, Spitalnikova S, Dlabalova B, Malirova E, Vizda J, Svilias I et al. Universal screening detects two-times more thyroid disorders in early pregnancy than targeted high-risk case finding. Eur $\mathbf{J}$ Endocrinol. 2010;163(4):645-50.

9. Matalon S, Sheiner E, Levy A, Mazor M, Wiznitzer A. Relationship of treated maternal hypothyroidism and perinatal outcome. J Reprod Med. 2006;51(1):59-63. 
10. Sharma Partha, Mukhopadhyay Partha. Hypothyroidism in pregnancy. Obstet Gynecol India. 2007;57(4):331-4.

11. Iskandar I, Srinivasan R, Simm A, Renee C. Maternal hypothyroidism in early and late gestation: effects of neonatal and obstetric outcome. Clin Endocrinol. 2005;63:560-5.

Cite this article as: Sisodia J, Samant M. Antenatal thyroid screening and its clinical correlation. Int J Reprod Contracept Obstet Gynecol 2017;6:1864-70. 